\title{
Isolation of Corynebacterium falsenii and description of Corynebacterium aquilae sp. nov., from eagles
}

\author{
J. F. Fernández-Garayzábal, ${ }^{1}$ R. Egido, ${ }^{1}$ A. I. Vela, ${ }^{1}$ V. Briones, ${ }^{1}$ \\ M. D. Collins, ${ }^{2}$ A. Mateos, ${ }^{1}$ R. A. Hutson, ${ }^{2}$ L. Domínguez ${ }^{1}$ and J. Goyache ${ }^{1}$ \\ 'Departamento de Patología Animal I (Sanidad Animal), Facultad de Veterinaria, Universidad \\ Complutense, 28040 Madrid, Spain \\ ${ }^{2}$ School of Food Biosciences, University of Reading, Reading RG6 6AP, UK
}

Correspondence

J. F. Fernández-Garayzábal garayzab@vet.ucm.es
Corynebacteria represent a major group of diphtheroid organisms within the Gram-positive, high- $\mathrm{G}+\mathrm{C}$ content Actinobacteria. The genus Corynebacterium has undergone considerable expansion in the past decade and, at the time of writing, over 50 species are recognized. Corynebacteria have been isolated from a wide range of environments (e.g. dairy products, soil, sewage, sediments, aquatic sources and animals) but the vast majority of novel species described in recent years have originated from human clinical sources (e.g. Funke et al., 1997, 1998; Sjödén et al., 1998; Collins et al., 1999a; Renaud et al., 2001), due to increasing concern about their potential pathogenic significance (Lagrou et al., 1998; Riegel, 1998). Corynebacteria also occur as part of the indigenous flora of animals other than man, but presently there is little information on the nature of these corynebacterial species and their host distribution. However, there are indications from the implementation of improved molecular taxonomic methodologies that much new corynebacterial species diversity remains to be discovered from animal sources (e.g. Fernández-Garayzábal et al., 1997, 1998; Pascual et al., 1998; Collins et al., 1999b,

Published online ahead of print on 13 January 2003 as DOI 10.1099/ ijs.0.02533-0.

The GenBank/EMBL/DDBJ accession number for the 16S rRNA gene sequence of strain CECT $5993^{\top}$ is AJ496733. 2001a, b). In the course of a study of the normal flora of the respiratory tract of eagles, we have characterized seven Corynebacterium-like organisms by using phenotypic, molecular chemical and molecular genetic methods. Based on the results of this study, we report the isolation of Corynebacterium falsenii from birds for the first time and describe a hitherto unknown Corynebacterium species, Corynebacterium aquilae sp. nov.

Bacterial strains S-102 and S-107 were isolated from the mouth of an adult and a juvenile Spanish Imperial eagle (Aquila adalberti), respectively. Five strains were isolated from Golden eagles (Aquila chrysaëtos), three (S-613 ${ }^{\mathrm{T}}, \mathrm{S}-622$ and S-623) from choanae and two (S-672 and S-676) from trachea. Eagles were housed in a rehabilitation centre located in the region of Castilla-La Mancha, Spain. All strains were isolated on Columbia sheep-blood agar plates (bioMérieux) and incubated for $48 \mathrm{~h}$ at $37^{\circ} \mathrm{C}$ under aerobic and anaerobic (AnaeroGen; Oxoid) conditions. The strains were characterized biochemically by using the API Coryne (version 2.0), API $50 \mathrm{CH}$ and API ZYM systems (bioMérieux) according to the manufacturer's instructions. The API $50 \mathrm{CH}$ strips were read after up to 7 days incubation at $37^{\circ} \mathrm{C}$. The CAMP (Christie-Atkins-MunchPetersen) test with Staphylococcus aureus ATCC 25923 was performed according to standard procedures (Funke et al., 1997). Lipophilic requirements were determined by growing 
the isolates in brain-heart infusion agar supplemented with $1 \%$ Tween 80 , in comparison with brain-heart infusion agar that lacked lipid supplementation. Cell-wall murein was prepared by mechanical disruption of cells and analysis of complete acid hydrolysates, as described by Schleifer \& Kandler (1972). Fatty acid methyl esters were prepared and analysed as described by Kämpfer \& Kroppenstedt (1996). The presence of mycolic acids was investigated by GLC analysis of trimethylsilylated derivatives (TMS-MAME) (Klatte et al., 1994). For 16S rRNA gene sequence analysis, a large fragment (approx. 1450 bases) of the 16S rRNA gene of the isolates was amplified by PCR and sequenced directly by using a Taq DyeDeoxy Terminator Cycle Sequencing kit and a model 373A automatic DNA sequencer (both from Applied Biosystems). The closest known relatives of the new isolates were determined by performing a database search. A phylogenetic tree was constructed according to the neighbour-joining method with the program NEIGHBOR (Felsenstein, 1989). The stability of the groupings was estimated by bootstrap analysis ( 500 replications) by using the programs DNABOOT, DNADIST, NEIGHBOR and CONSENSE (Felsenstein, 1989).

The seven strains consisted of Gram-positive, non-motile, non-spore-forming, catalase-positive rods. Colonies were non-haemolytic and non-lipophilic and the CAMP test result was negative. All strains produced acid from glucose and ribose but not from xylose, mannitol, lactose or sucrose. None of the strains reduced nitrate and they did not hydrolyse aesculin, gelatin or urea. Reactions for pyrazinamidase and alkaline phosphatase were positive, but no activity was detected for pyrrolidonyl arylamidase, $\beta$ glucuronidase, $\beta$-glucosidase, $\alpha$-glucosidase or $N$-acetyl- $\beta$ glucosaminidase. Three strains (S-107, S-672 and S-676) produced acid from maltose, whereas the other four strains did not. The former three strains grew on Columbia sheepblood agar as whitish, circular, smooth colonies that developed a yellowish pigment after $48-72 \mathrm{~h}$ incubation. This pigmentation is produced by only a few non-lipophilic Corynebacterium species (Funke et al., 1997; Sjödén et al., 1998). Two different numerical profiles were obtained with the commercial API Coryne system: 2100304 (strains S-107, S-613 ${ }^{\mathrm{T}}, \mathrm{S}-622$ and S-623) and 2100324 (S-102, S-672 and S-676), which correspond to a good identification of Corynebacterium jeikeium and an excellent identification within the genus Corynebacterium, respectively. However, C. jeikeium is lipophilic and does not grow anaerobically (Funke et al., 1997), whereas the seven eagle isolates were able to grow under anaerobic conditions and were non-lipophilic.

The eagle isolates were further characterized biochemically by using the API $50 \mathrm{CH}$ and API ZYM systems. All strains produced acid from D-fructose, D-mannose, glycerol, ribose, $\mathrm{N}$-acetylglucosamine and galactose. None of the strains produced acid from maltose, trehalose, D-xylose, L-xylose, mannitol, lactose, sucrose, erythritol, D-arabinose, L-arabinose, adonitol, methyl $\beta$-xyloside,
L-sorbose, rhamnose, inositol, sorbitol, methyl $\alpha$-Dmannoside, methyl $\alpha$-D-glucoside, amygdalin, arbutin, salicin, cellobiose, melibiose, inulin, melezitose, D-raffinose, xylitol, $\beta$-gentibiose, D-turanose, D-lyxose, D-tagatose, D-fucose, L-fucose, D-arabitol, L-arabitol, 2-ketogluconate, 5-ketogluconate or glycogen. All strains gave positive reactions for alkaline phosphatase, ester lipase C8, esterase C4, naphthol-AS-BI-phophohydrolase, acid phosphatase and leucine arylamidase. No activity was detected for trypsin, $\beta$-glucuronidase, $\alpha$-glucosidase, $\beta$-glucosidase, $\alpha$ mannosidase, $\alpha$-fucosidase, $\alpha$-galactosidase, $\beta$-galactosidase, $N$-acetyl- $\beta$-glucosaminidase, valine arylamidase or cystine arylamidase. Strains S-102, S-672 and S-676 gave a positive reaction for lipase $\mathrm{C} 14$ and were negative for chymotrypsin. On the other hand, strains S-107, S-613 ${ }^{\mathrm{T}}$, S-622 and S-623 gave a positive reaction for chymotrypsin and were negative for lipase C14. Morphological and biochemical characteristics of both groups of strains were consistent with their provisional assignment to the genus Corynebacterium.

In order to investigate the phylogenetic relationships of the two groups of strains, their $16 \mathrm{~S}$ rRNA gene sequences were determined by direct sequencing of in vitro-amplified rRNA gene products. The almost-complete 16S rRNA gene sequences $(>1400 \mathrm{nt})$ of two representative strains of each group (S-676, S-672, S-622 and S-613 ${ }^{\mathrm{T}}$ ) and approximately $1000 \mathrm{nt}$ of those of the other three strains were determined and subjected to comparative analysis. The isolates from eagles formed two separate phylogenetic groups that were consistent with their phenotypic division, with $>99.5 \%$ 16S rRNA sequence similarity within groups. Sequence searches of GenBank revealed that the unknown isolates belonged phylogenetically to the genus Corynebacterium (data not shown). Treeing analysis clearly demonstrated that the two groups of unidentified strains were phylogenetically separate from each other. The 16S rRNA gene sequences of strains S-672 and S-676 displayed 99.9\% similarity with C. falsenii CCUG $33651^{\mathrm{T}}$, whereas the second group of strains was phylogenetically distinct from all previously described Corynebacterium species. The genotypic identification of isolates S-102, S-672 and S-676 as $C$. falsenii is consistent with their phenotypic characteristics, although the three eagle strains failed to produce acid from glycogen and did not hydrolyse urea with the API Coryne system. However, the aforementioned strains did hydrolyse urea using Christensen's urea medium, which also agrees with previous results of studies on C. falsenii (Sjödén et al., 1998). C. falsenii has been isolated from different, normally sterile body sites in humans (Sjödén et al., 1998), but to our knowledge this is the first isolation of this species from birds.

A tree constructed by using the neighbour-joining method, depicting the phylogenetic position of the second group of eagle isolates within the genus Corynebacterium, is shown in Fig. 1. The unknown group (as exemplified by strain $\mathrm{S}-613^{\mathrm{T}}$ ) formed a distinct lineage within the genus Corynebacterium, loosely associated with a small subcluster 




Fig. 1. Unrooted tree based on $16 \mathrm{~S}$ rRNA gene sequences, showing the phylogenetic relationships of Corynebacterium aquilae sp. nov. Bootstrap values (percentage of 500 replications) are given at branching points. Bar, $1 \%$ sequence divergence.

of species that included Corynebacterium diphtheriae, the type species of the genus. However, bootstrap resampling showed that the unidentified eagle strains did not share a particularly close affinity with any member of this subcluster of species. Sequence similarity values confirmed the genotypic distinctiveness of this group of eagle isolates, as the highest values were shared with Corynebacterium argentoratense CIP $104296^{\mathrm{T}}(96 \cdot 4 \%)$, Corynebacterium felinum CCUG $39943^{\mathrm{T}}(95 \cdot 1 \%)$, Corynebacterium ulcerans NCTC $7910^{\mathrm{T}}(95 \cdot 6 \%)$, Corynebacterium vitaeruminis DSM $20294^{\mathrm{T}}(95 \cdot 2 \%)$, C. diphtheriae NCTC $11397^{\mathrm{T}}(95 \cdot 1 \%)$, Corynebacterium testudinoris CCUG $41823^{\mathrm{T}}(95 \cdot 9 \%)$, Corynebacterium kutscheri CIP $103423^{\mathrm{T}}(94 \cdot 1 \%)$ and Corynebacterium pseudotuberculosis NCTC $3450^{\mathrm{T}}$ (95·4\%). Other corynebacterial species displayed substantially lower levels of similarity. To confirm the phylogenetic placement of the unknown eagle bacterial strains, cell-wall and lipid analyses were performed on a representative strain $\left(\mathrm{S}-613^{\mathrm{T}}\right)$. Cell-wall murein analysis revealed the presence of meso-diaminopimelic acid, which is consistent with the definition of the genus Corynebacterium. Lipid analyses also reinforced the placement of the unknown strains within this genus, as short-chain mycolic acids (length C30-C36) and major amounts of straight-chain saturated $\left(\mathrm{C}_{14: 0}\right.$, $\mathrm{C}_{16: 0}$ and $\left.\mathrm{C}_{18: 0}\right)$ and monounsaturated $\left(\mathrm{C}_{16: 1} \omega 9 c\right.$ and $\left.\mathrm{C}_{18: 1} \omega 9 c\right)$ cellular fatty acids were detected. Thus it is clear, from both phenotypic and molecular genetic evidence, that the second group of eagle isolates represents a novel species within the genus Corynebacterium. Biochemically, the novel species can be readily distinguished from all currently recognized corynebacterial species. In addition, $16 \mathrm{~S}$ rRNA gene treeing analysis and sequence divergence values of $>3 \%$ between the unknown strains and all Corynebacterium species with validly published names show unequivocally that they represent a hitherto unrecognized species (Stackebrandt \& Goebel, 1994). Therefore, based on both phylogenetic and phenotypic criteria, it is evident that the unidentified strains merit classification as a novel species of the genus Corynebacterium, for which the name Corynebacterium aquilae sp. nov. is proposed. Tests that are useful for the differentiation of $C$. aquilae from its nearest phylogenetic relatives are shown in Table 1.

\section{Description of Corynebacterium aquilae sp. nov.}

Corynebacterium aquilae (a'qui.lae. N.L. gen. n. aquilae pertaining to the eagle, Aquila).

Cells are Gram-positive, non-motile, non-spore-forming rods. Colonies are whitish, low convex, dry, rough and 1-2 $\mathrm{mm}$ in diameter after $48 \mathrm{~h}$ incubation at $37^{\circ} \mathrm{C}$ on sheep-blood agar. Facultatively anaerobic, catalase-positive and oxidase-negative. Non-haemolytic, CAMP-negative and non-lipophilic. Nitrate is not reduced. Acid is produced from D-glucose, D-fructose, D-mannose, glycerol, ribose, $\mathrm{N}$-acetylglucosamine and galactose, but not from maltose, trehalose, D-xylose, L-xylose, mannitol, lactose, sucrose, erythritol, D-arabinose, L-arabinose, adonitol, methyl $\beta$ xyloside, L-sorbose, rhamnose, inositol, sorbitol, methyl $\alpha$-D-mannoside, methyl $\alpha$-D-glucoside, amygdalin, arbutin, salicin, cellobiose, melibiose, inulin, melezitose, D-raffinose,

Table 1. Characteristics that differentiate C. aquilae $\mathrm{sp}$. nov. from its nearest phylogenetic relatives

Taxa: 1, C. aquilae CECT $5993^{\mathrm{T}}$; 2, C. argentoratense CIP $104296^{\mathrm{T}}$; 3, C. testudinoris CCUG $41823^{\mathrm{T}}$; 4, C. felinum CCUG $39943^{\mathrm{T}}$; 5 , C. vitaeruminis; 6, C. diphtheriae; 7, C. ulcerans CCUG $2798^{\mathrm{T}} ; 8$, C. pseudotuberculosis. Data for C. vitaeruminis, C. diphtheriae and C. pseudotuberculosis are from the API Coryne system database and Collins et al. (2001b). +, Positive reaction; -, negative reaction; $+\mathrm{W}$, weakly positive reaction; $\mathrm{V}$, variable reaction; $\mathrm{V}+$, most strains positive; $\mathrm{V}-$, most strains negative; ND, not determined.

\begin{tabular}{|c|c|c|c|c|c|c|c|c|}
\hline Characteristic & 1 & $2^{*}$ & $3 \dagger$ & $4 末$ & 5 & 6 & $7 \S$ & $8 \S$ \\
\hline Nitrate reduction & - & - & + & - & + & $\mathrm{v}+$ & - & -11 \\
\hline Hydrolysis of aesculin & - & - & + & - & + & - & - & - \\
\hline Urease & - & - & - & - & + & - & + & + \\
\hline \multicolumn{9}{|l|}{ Acid production from: } \\
\hline Maltose & - & - & + & + & + & + & + & + \\
\hline Sucrose & - & - & + & - & + & - & - & -11 \\
\hline \multicolumn{9}{|l|}{ Activity of: } \\
\hline Pyrazinamidase & + & + & - & + & + & - & - & - \\
\hline Pyrrolidonyl arylamidase & - & - & - & + & + & - & - & - \\
\hline Alkaline phosphatase & + & $\mathrm{v}-$ & - & - & $\mathrm{V}$ & - & + & $\mathrm{ND}$ \\
\hline Acid phosphatase & + & $\mathrm{V}$ & $+\mathrm{w}$ & - & ND & $\mathrm{ND}$ & ND & + \\
\hline$\alpha$-Glucosidase & - & - & $\mathrm{V}$ & + & $\mathrm{ND}$ & + & + & $\mathrm{V}$ \\
\hline
\end{tabular}

${ }^{\star}$ C. argentoratense differs also from $C$. aquilae by its inability to produce acid from galactose and by exhibiting cystine arylamidase activity.

$\dagger C$. testudinoris is $\alpha$-chymotrypsin-negative and $\beta$-glucosidasepositive.

$\ddagger C$. felinum is $\alpha$-chymotrypsin-negative.

$\S C$. ulcerans and C. pseudotuberculosis display reverse CAMP reactions.

IIVariable, according to Funke et al. (1997). 
xylitol, $\beta$-gentibiose, D-turanose, D-lyxose, D-tagatose, D-fucose, L-fucose, D-arabitol, L-arabitol, 2-ketogluconate, 5-ketogluconate or glycogen. Gelatin, urea and aesculin are not hydrolysed. Alkaline and acid phosphatases, ester lipase C8, esterase C4, naphthol-AS-BI-phophohydrolase, leucine arylamidase and chymotrypsin activities are detected. No activity is detected for lipase C14, $\alpha$-glucosidase, $\beta$ glucosidase, $\beta$-glucuronidase, $\alpha$-mannosidase, $\alpha$-galactosidase, $\beta$-galactosidase, $\alpha$-fucosidase, $N$-acetyl- $\beta$-glucosaminidase, valine arylamidase, trypsin or cystine arylamidase. Cell wall contains meso-diaminopimelic acid. Mycolic acids $\left(\mathrm{C}_{30^{-}}\right.$ $\mathrm{C}_{36}$ ) are present. Fatty acids are of the straight-chain saturated $\left(\mathrm{C}_{14: 0}, \mathrm{C}_{16: 0}\right.$ and $\left.\mathrm{C}_{18: 0}\right)$ and monounsaturated $\left(\mathrm{C}_{16: 1} \omega 9 c\right.$ and $\left.\mathrm{C}_{18: 1} \omega 9 c\right)$ types.

The type strain, $\mathrm{S}-613^{\mathrm{T}}\left(=\mathrm{CECT} 5993^{\mathrm{T}}=\mathrm{CCUG} 46511^{\mathrm{T}}\right)$, was isolated from the choanae of the Golden eagle $(A$. chrysaëtos).

\section{Acknowledgements}

The authors thank N. Montero for her technical assistance.

\section{References}

Collins, M. D., Bernard, K. A., Hutson, R. A., Sjödén, B., Nyberg, A. \& Falsen, E. (1999a). Corynebacterium sundsvallense sp. nov., from human clinical specimens. Int J Syst Bacteriol 49, 361-366.

Collins, M. D., Hoyles, L., Lawson, P. A., Falsen, E., Robson, R. L. \& Foster, G. (1999b). Phenotypic and phylogenetic characterization of a new Corynebacterium species from dogs: description of Corynebacterium auriscanis sp. nov. J Clin Microbiol 37, 3443-3447.

Collins, M. D., Hoyles, L., Foster, G., Sjödén, B. \& Falsen, E. (2001a). Corynebacterium capitovis sp. nov., from a sheep. Int J Syst Evol Microbiol 51, 857-860.

Collins, M. D., Hoyles, L., Hutson, R. A., Foster, G. \& Falsen, E. (2001b). Corynebacterium testudinoris sp. nov., from a tortoise, and Corynebacterium felinum sp. nov., from a Scottish wild cat. Int J Syst Evol Microbiol 51, 1349-1352.

Felsenstein, J. (1989). PHYLIP - phylogeny inference package (version 3.2). Cladistics 5, 164-166.
Fernández-Garayzábal, J. F., Collins, M. D., Hutson, R. A., Fernández, E., Monasterio, R., Marco, R. \& Domínguez, L. (1997). Corynebacterium mastitidis sp. nov., isolated from milk of sheep with subclinical mastitis. Int J Syst Bacteriol 47, 1082-1085.

Fernández-Garayzábal, J. F., Collins, M. D., Hutson, R. A., Gonzalez, I., Fernández, E. \& Domínguez, L. (1998). Corynebacterium camporealensis sp. nov., associated with subclinical mastitis in sheep. Int J Syst Bacteriol 48, 463-468.

Funke, G., von Graevenitz, A., Clarridge, J. E., III \& Bernard, K. A. (1997). Clinical microbiology of coryneform bacteria. Clin Microbiol Rev 10, 125-159.

Funke, G., Osorio, C. R., Frei, R., Riegel, P. \& Collins, M. D. (1998). Corynebacterium confusum sp. nov., isolated from human clinical specimens. Int J Syst Bacteriol 48, 1291-1296.

Kämpfer, P. \& Kroppenstedt, R. M. (1996). Numerical analysis of fatty acid patterns of coryneform bacteria and related taxa. Can J Microbiol 42, 989-1005.

Klatte, S., Kroppenstedt, R. M. \& Rainey, F. A. (1994). Rhodococcus opacus sp. nov., an unusual nutritionally versatile Rhodococcusspecies. Syst Appl Microbiol 14, 355-360.

Lagrou, K., Verhaegen, J., Janssens, M., Wauters, G. \& Verbist, L. (1998). Prospective study of catalase-positive coryneform organisms in clinical specimens: identification, clinical relevance, and antibiotic susceptibility. Diagn Microbiol Infect Dis 30, 7-15.

Pascual, C., Foster, G., Alvarez, N. \& Collins, M. D. (1998). Corynebacterium phocae sp. nov., isolated from the common seal (Phoca vitulina). Int J Syst Bacteriol 48, 601-604.

Renaud, F. N. R., Aubel, D., Riegel, P., Meugnier, H. \& Bollet, C. (2001). Corynebacterium freneyi sp. nov., $\alpha$-glucosidase-positive strains related to Corynebacterium xerosis. Int J Syst Evol Microbiol 51, 1723-1728.

Riegel, P. (1998). Bacteriological and clinical aspects of Corynebacterium. Ann Biol Clin 56, 285- 296 (in French).

Schleifer, K. H. \& Kandler, O. (1972). Peptidoglycan types of bacterial cell walls and their taxonomic implications. Bacteriol Rev 36, 407-477.

Sjödén, B., Funke, G., Izquierdo, A., Akervall, E. \& Collins, M. D. (1998). Description of some coryneform bacteria isolated from human clinical specimens as Corynebacterium falsenii sp. nov. Int J Syst Bacteriol 48, 69-74.

Stackebrandt, E. \& Goebel, B. M. (1994). Taxonomic note: a place for DNA-DNA reassociation and 16S rRNA sequence analysis in the present species definition in bacteriology. Int J Syst Bacteriol 44, 846-849. 